\title{
Towards peer education prevention of school dropout: An exploratory analysis of an action-research study
}

\section{Gabriella Colucci ${ }^{1}$}

University of Teacher Education (HEP-BEJUNE), Biel/Bienne (Switzerland)

\section{Francesco Arcidiacono}

University of Teacher Education (HEP-BEJUNE), Biel/Bienne (Switzerland)

\begin{abstract}
This paper presents the exploratory analysis of an action-research into dropout prevention in an Italian secondary school. By taking into account the representations of teachers, students and parents, different activities of peer education have been implemented during the school year in a city of Sardinia in order to promote school success. The study is based on a mixed-methods design, including focus groups with teachers, students and parents, as well as classroom observations. The action-research consists of different interventions: firstly, the participants' representations of school dropout have been collected; then, a specific program of peer education has been proposed through activities of role-playing, simulations, brainstorming, and improvement of life skills (during training meetings with the participants). Thereafter, the action-research has been qualitatively analysed, with the findings indicating possible directions of re-creating school practices that could have potential benefits in preventing dropout.
\end{abstract}

Key-words: dropout, action-research, peer education, qualitative analysis, life skills education

\section{Introduction}

In the past few decades, school dropout and school wellbeing have become important in public debates within and across different European countries, as two sides of the same issue. The current discussions concern the question of how to guarantee a high quality school system and an adequate level of wellbeing for students and teachers, as the conditions, among others, for providing direction towards a new economy of knowledge (Benvenuto

1 gabricolucci@libero.it 
et al., 2000). In contexts of constant evolution and change, the possibility of ensuring sufficient wellbeing and preventing school dropout have been connected to different attempts (in terms of policies and actions), strongly based on the societal, cultural and political issues of each country. However, school dropout is still a complex phenomenon, historically, culturally and politically situated, involving at least a double-sided responsibility: on the one side, the school as an institution seems to be unable to attend to its role with all the students; on the other side, students seem to be not taking advantage of the opportunities that school is offering as a societal institution. Far from having a possible solution to these questions, the goal of this paper is to consider an action-research implemented to prevent dropout in an Italian secondary school and to analyse the results of this attempt in order to promote school success. We intend to present and account for the representations of teachers, students and parents of different activities of peer education that they experienced during a school year. Throughout the qualitative analysis of the implemented action-research, we intend to better understand the relation between the promotion of peer education and the school-family relationships as factors that can promote successful school practices.

The paper is organised as follows: in the first part, a short reflection on some theoretical concepts will be offered in order to point out the main elements that frame the research we have conducted. Thereafter, the methodological action we have designed will be presented, as well as the different interventions that constitute the core of our action-research. Furthermore, the findings of the qualitative analysis we have conducted will be offered as exploratory indicators of various interrelated factors at the core of our study (such as peer education, school-family relationships and school success). In the final part of the paper, some implications will be highlighted in terms of lessons learned.

\section{School dropout and the promotion of peer education}

The notion of school dropout has been the focus of different studies in various fields, mainly psychology and education. In this section of the paper, we are not aiming at revisiting the vast literature in these fields ${ }^{2}$ : to the contrary, we will focus on specific aspects of the phenomenon, by taking a precise, although partial, perspective.

Research shows that leaving school early is the outcome of a long process of disengagement from school (Christenson et al., 2001), and that dropout arises from an accumulation of various risk factors throughout children's schooling that peak once in high school (Hammond et al., 2007). In this vein, we can affirm that dropout is a process that begins before high school, when students

2 For a comprehensive review of dropout interventions, cf. Lehr et al. (2003). 
exhibit identifiable warning signs at least one to three years before they drop out (Allensworth, 2005; Roderick, 1994; Rumberger, 2004). Furthermore, most students who drop out tend to do so relatively early on in their high school careers. Definitions of dropout can vary according to the nature of the research and data available. In this study, we assume that school dropout can be defined as "the process through which there are delays, postponements and early exits from the school course, consequently it is all the failures" (Besozzi, 1997, p. 151). Failure includes, in this sense, the exit from the educational system, elusion of the obligation (compulsory education), delays when measured against the norms according to age, little efficiency and performance, as well as very poor outcomes (Morgagni, 1998; Colucci, 2016).

Within the Italian context, the indicators of Early School Leavers (ESL) for the students of secondary level age that are out of the national system of education were $17.6 \%$ (in 2012) while the EU mean was $12.8 \%$. Italy is placed almost at the end of the EU results and the difference with the other countries is especially marked with respect to male students $(20.5 \%$ versus $14.5 \%)$, more than with female students (14.5\% versus $11.0 \%)$. More specifically, certain areas of Italy, like Sardinia, have a global indicator of $25.8 \%$ for school dropout. These indicators show that Italy is a country in which school dropout is crucial because it includes components not only related to schooling (withdrawal, rejection, repeating), but also external factors connected to cultural, social, existential and psychological sides (Liverta Sempio et al., 1999).

Within the above mentioned frame, the perspective of a restorative school (Zehr, 1990) seems relevant in order to highlight the need for reparative practices and a view of the school as a community including different actors (teachers, students, parents) handling school problems, such as dropout. Examining the actual situation in Italy involves studying the perceptions and the representations of the different actors involved in the school system, in order to explore their realities and to look for specific interventions related to local and particular contexts. In our opinion, the model of peer education, inspired by the theories of life skills (World Health Organization, 1994; 2003) and social learning (Bandura, 1986; 1997), can play a crucial role. This option seems to be sustained by previous experiences, such as the peace circle (Boyes-Watson \& Pranis, 2015; Bussu et al., 2016; Bussu, Boyes-Watson \& Veloria, 2017), in which the possibility of re-creating a positive social climate in the school has shown the potential benefits of the approach in preventing school dropout and in promoting students' success. Peer education consists of an efficient method in which members of a group take responsibility, are trained and then re-inserted in their group in order to realise specific activities with their peers (Boda, 2001; 2006; Franzese, 2009; Croce \& Gnemmi, 2003). We are aware that promoting successful school completion for students who are at risk of dropping out is challenging in light of the 
current national reform efforts to achieve high standards, social promotion and educational accountability (Christenson \& Thurlow, 2004). Interventions must address the particular academic needs of the students, by providing an appropriate type of curriculum, teaching staff, instructional progress, and even schedule and location. Successful programs should mix academic and vocational studies, providing a more individualised instruction, and using the resources which are more sensitive and responsive to the students' needs (Bullis, 1986; Olsen \& Edwards, 1982). The need to create opportunities for success and to provide necessary supports for school's actors is thus a priority in such a context. The action-research implemented in a secondary school in Italy is therefore the result of the situation described above.

We are convinced that an analysis of the implementation of measures attempting to sustain the prevention of school dropout could be also useful in terms of promotion of peer education and students' success and in order to identify possible directions of re-creating successful school practices that could have different potential benefits. More particularly, the following research questions are addressed in the present study: To what extent can educational interventions promote successful reparative practices with potential beneficial effects on dropout prevention? Which are the necessary conditions for successfully implementing an intervention that promotes collaboration between school actors?

\section{Methodology}

\section{Context and participants}

The present study is a part of a research-action conducted during the academic year 2014/15 in 3 classes (grade 6) of a secondary school (Istituto Comprensivo "Li Punti") of Sassari (Italy). The research was conducted in three parts (explorative phase, action phase, and monitoring phase) involving teachers, students and parents who were requested to fill in questionnaires, as well as to participate in focus groups, meetings and trainings. The study we present here is based on the qualitative analysis of two sets of data (focus groups and observations) collected during an academic year, according to the above mentioned steps.

Participants include a group of 10 teachers ( 7 women, 3 men; age 35-61; mean age: 50.2 ) of the selected school, 11 students (6 girls, 5 boys; age: 11-14; mean age: 11.38), and 9 parents (mothers, age $36-49$; mean age: 43.7 ).

\section{Explorative phase}

During the period of November-December 2014, a preliminary phase was developed in order to foster occasions for reflection among the participants. 
In particular, different focus groups ${ }^{3}$ were conducted with the goal of detecting the school representations of the actors involved in the school systems, as well as the possible ways to collaborate in improving situations for everybody. Two focus groups were conducted with parents, two focus groups were conducted with the teachers and two focus groups were conducted with students. Parents and students involved in focus groups were not from the same families. The topics of the focus groups were the interrelated roles of school, family and students and the phenomenon of school dropout: the tools for preventing it and possible interventions.

\section{Action phase}

During the period of February-May 2015, an educational intervention was implemented. Five meetings with the teachers were conducted, in which teachers were trained to develop their self-efficacy and life skills, and to integrate these aspects within didactic activities. Different tools were used during the training meetings, such as role-playing, simulations, brainstorming, plenaries and small-group activities to foster the promotion of life skills.

Simultaneously, four meetings with 11 students ( 6 girls; 5 boys) of three classes of grade 6 were conducted. These students were selected according to the results of the questionnaires administered at the beginning of the research project ${ }^{4}$. The goal of the training meetings was to develop the skills and relational competencies necessary to enhance a positive climate in the classroom and to ensure school success. Two further meetings also involved teachers. Afterwards, three participant observations were conducted by selected peer educators during the classroom activities in three classes.

\section{Monitoring phase}

During the period of April-May 2015, the concluding intervention was conducted (through the administration of questionnaires) in order to detect the degree of satisfaction and success of the educational programs in the school.

3 Focus groups were conducted at school by a researcher, with the presence of two observers. The session was developed in three parts: group introduction, topic introduction and discussion, conclusion. Data were audio-recorded (a consent form had been signed by participants).

4 ASP/G Scale of perceived social self-efficacy and ASCP Scale of perceived school self-efficacy (Caprara, 2001); The hope scale (Snyder et al., 1991); Life Orientation Test (Scheier et al., 1994). Students with the highest self-efficacy were selected, since it can imply that they can favor different beneficial effects on students at risk of school dropout. 


\section{Qualitative analysis and results}

In the present paper, we will focus exclusively on the data obtained through the focus groups and the observation of activities in classroom. The procedure we have followed is inductive and inspired by an idiographic perspective (Arcidiacono, 2015). In order to analyse the data, we proceeded with several steps: in an initial phase of the coding, we identified the participants' interventions for each topic of discussion; afterwards, we selected excerpts of talk as a collection of similar/different instances that account for a variety of possible answers. The software Nvivo was used for the organisation of the categories. In presenting the results of our qualitative analysis, we will account for the participants' perspectives of the different actors involved. Three subsections will follow, each corresponding to a respective group of participants (teachers, students and parents), in order to highlight, in a descriptive way, the various perspectives of the school actors during the various steps of the intervention. The idea is to list these categories and the arguments that participants invoked during the discussions ${ }^{5}$.

\section{Findings related to the teachers' perspectives}

During the focus groups, teachers discussed different topics connected to the main subjects of school dropout prevention and the promotion of school success. The elements that emerged from the qualitative analysis of teachers' discourses concern different categories (personal motivation, perceived role of the school and of family-school relationships, teacher-student relationships, prevention of school dropout and proposals) that are briefly presented below.

1a) Motivation: teachers expressed different positions towards their motivation to be teachers and to contribute to the prevention of school dropout rates and the promotion of students' success. In particular, the need for financial and personal stability was invoked as a main motive to leave other professional activities in order to work at school. There were also elements of chance, connected to the short time between the end of their academic education and the engagement as teachers at school, as well as their family expectations and traditions (e.g., the fact of having other teachers within the family, for instance, their parents or other relatives). In addition, their motivation was similarly inspired by a personal passion to teach, a vocational attitude and a will to be a teacher - a member of a very important educational community. These elements are presented as relevant in terms of teachers' positive attitudes in engaging (or at least in declaring a will to be engaged) in the interventions against school dropout performed at school during the academic year.

5 Only this bottom-up procedure is presented in this section. For a more global view on the different types of analysis that were performed, cf. Colucci (2015). 
1b) The role of the school and the relationship with the family: the teachers strongly recognised and highlighted the fundamental role of school in terms of educational agency, together with the family. However, the issue of discipline and respect was highlighted as crucial. In the teacher's discourse, the change of the family-school relationships is presented as the effect of a general crisis of many institutions. In addition, a lack of cultural and social stimuli (e.g., in the neighbourhood) also contribute to reinforcing the décalage between family and school, delegating to the latter some educational functions and responsibilities that are not fully elaborated within the family. The relations between school and family appear quite often in teachers' exchanges and constitute a relevant topic to better understand the actors' representations and ideas at the beginning of the intervention.

1c) The teacher-student relationship: the teachers highlighted the circularity of the relations among themselves, the students and the parents. More particularly, the relationship with the students was considered as a crucial dimension of the teachers' profession: teachers emphasised the experimental and developmental aspect of the school activities (in terms of the necessity to be always ready to adapt, modify and adjust positions and attitudes) and the relevance of including students in contributing to creating the conditions favouring better school dynamics. A fundamental element is the possibility for taking into account the students' expectations, their perception that school is the place to learn and to socialise, although some of the students were not able to declare these expectations, nor show an intrinsic motivation to attend the school. Teachers appeared to be really committed to this lack of motivation and they declared their engagement to improve the relationships with the students in ensuring their success and in promoting the measures to prevent school dropout.

1d) Prevention of school dropout and proposal: the teachers indicated having different positions towards the possible measures taken against school dropout. Some of them expressed their agreement with additional lessons to make up for any losses since the beginning of the academic year, while others considered it as a real failure. Failing exams ${ }^{6}$ was similarly considered as a possible solution. Some teachers sustained the idea that other types of didactic situations (e.g., the laboratories) could improve the students' motivation through practical activities that offer to students the possibility of expressing their own knowledge and experiences and to reflect on it with the teachers

6 In the specific context we have studied, failing exams is intended as a possible preventive measure, instead of a first step towards dropping out. Although research shows that failing exams and low academic achievement, even in low grade, are the precursors of dropping out and indicators of being at risk for dropping out, the participant teachers of our study propose it as a measure for preventing dropout. In the following section of the paper, the term "failing exams" will refer to this peculiar meaning. 
and the peers. However, these solutions require a new organisation within the school: the current national contract (established in 2007) indicates that these alternative types of education are non-mandatory rights-duties for workers, meaning that a restricted group of people should ensure its implementation only if they are available to invest their time and personal resources. This appears as relevant from the teachers' perspectives, because the current lack of resources does not allow schools to autonomously establish some extracurricular activities contributing to dropout prevention and improving the students' school success.

Table 1 below summarises the elements invoked by the teachers during the focus groups.

Table 1: Teachers' accounts of the invoked categories.

\begin{tabular}{|c|c|c|c|c|}
\hline Categories & $\begin{array}{c}\text { Personal } \\
\text { motivation }\end{array}$ & $\begin{array}{c}\text { Role of school } \\
\text { and family-school } \\
\text { relationships }\end{array}$ & $\begin{array}{c}\text { Teacher- } \\
\text { student } \\
\text { relationship }\end{array}$ & $\begin{array}{c}\text { Prevention and } \\
\text { proposals }\end{array}$ \\
\hline Indicators & $\begin{array}{l}\text { Stability } \\
\text { Chance } \\
\text { Family } \\
\text { background } \\
\text { Interest and } \\
\text { passion }\end{array}$ & $\begin{array}{l}\text { Relevance of school as } \\
\text { educational agency } \\
\text { Inappropriateness and } \\
\text { institutional crisis } \\
\text { Lack of parental } \\
\text { authorities and values }\end{array}$ & $\begin{array}{l}\text { Change of } \\
\text { approach } \\
\text { Circularity }\end{array}$ & $\begin{array}{l}\text { Professional training } \\
\text { Didactic situations } \\
\text { Failing exams } \\
\text { Make-up lessons }\end{array}$ \\
\hline
\end{tabular}

\section{Findings related to the parents' perspective}

From the beginning of the research-action project, parents have instituted a positive relationship with other school actors. The topics and elements they have highlighted concern the role of school and family-school relationships, the specific relationship between teachers and students as well as among peers, and the suggestions as to resources and proposals for improving school success and preventing dropout.

2a) Role of school and family-school relationships: the parents declared their belief regarding the relevance of school as an educational agency, together with the family, for young people. This is the case especially at the age of 11 , when students have to deal with different changes in their development and lives. Apart from taking into account the adolescents' problems, schools need to promote a social change through competent teachers having the capacity to face some parental disinterest. The issue of a lack of collaboration between school and the family is perceived as crucial by the parents. The limited presence and participation of family members in school meetings and interactions with teacher was recognised as the main indicator of a difficult relationship between the two systems (the family and school). 
2b) Teacher-student relationships and peer relationships: the parents highlighted a need for improved reciprocity, integration and solidarity among school actors, especially regarding student-teacher relations. According to the parents, teachers should be more attentive and supportive in taking into account the students' difficulties, in order to recognise their efforts and to improve their capacity for dialogue.

2c) Didactic offer and proposals: the parents highlighted a lack of extracurricular activities (e.g., theatre) and school-family meetings. They indicated that raising awareness among students of topical problems (such as bullying or drugs' addiction) is needed, not least in order to recognise some transversal competencies of teachers. However, certain aspects of the teachers' attitudes were considered problematic, especially regarding their negative or critical attitude to their conduct or professional competence being. What is missing in the parents' discourses is a movement from a destruens phase, in which negative and dysfunction aspects are highlighted, to a costruens phase as an operational modality within the school context.

Table 2 below summarises the elements invoked by the parents during the focus groups.

Table 2: Parents' accounts for the invoked categories.

\begin{tabular}{|l|l|l|l|}
\hline Categories & \multicolumn{1}{|c|}{$\begin{array}{c}\text { Role of school } \\
\text { and family-school } \\
\text { relationships }\end{array}$} & $\begin{array}{c}\text { Teacher-student } \\
\text { relationship }\end{array}$ & Prevention and proposals \\
\hline Indicators & $\begin{array}{l}\text { Adolescent problems } \\
\text { Teachers' competencies } \\
\text { Parental disinterest } \\
\text { Weak collaboration }\end{array}$ & $\begin{array}{l}\text { Need for collaboration, } \\
\text { dialogue and support } \\
\text { Teachers' indifference } \\
\text { Parents' collaboration }\end{array}$ & $\begin{array}{l}\text { Extracurricular activities } \\
\text { Sensitisation } \\
\text { School-family meetings } \\
\text { Teachers' competencies } \\
\text { (transversal, professional) }\end{array}$ \\
\hline
\end{tabular}

\section{Findings related to the students' perspective}

Students expressed their points of view on their expectations, their idea of measures to prevent dropout and some proposals that could be applied at school. Despite their young age and the fact they are at the beginning of secondary school (grade 6), they highlighted interesting elements to be taken into account in designing school interventions.

3a) Expectations: apart from the fact that all the students highlighted the relevance of obtaining a diploma, their expectations towards the school system concern personal and social dimensions of their everyday lives, such as the need to be listened to, to have the opportunity to learn and to be evaluated according to their capacities. In general, their discourses indicate a perceived lack of trust and difficulties in finding a proper place within the school system. 
3b) Prevention and proposals: in their discourses, the students indicated the need for interventions aimed at people living in at-risk areas (for socio-economic reasons) in order to promote more professional training and education. In discussing the possible ways to prevent school dropout, the students indicated the possibility of failing exams, but also the need for different activities (such as laboratories and make-up lessons) and the valorisation of the excellence that already exists. Their proposals involved the possibility of having more time at school, e.g., extended school time for some classes, or benefiting from the help of other more competent students. Thereafter, the issue of peer tutoring was highlighted as a possible way of improving students' school success, aimed at fostering the students' own interests: this point is crucial, because the perspectives of the students need to be met with the same level of openness from the teachers' side, a condition which needs to be shared by all school actors. A change towards an increased focus on the students' interests is also connected to a more global revision of the school curriculum, involving other elements (political, social, and pedagogical) that have to be taken into account.

Table 3 below summarises the elements invoked by the students during the focus groups.

Table 3: Students' accounts for the invoked categories.

\begin{tabular}{|l|l|l|l|}
\hline Categories & \multicolumn{1}{|c|}{ Expectations } & \multicolumn{1}{c|}{ Prevention } & \multicolumn{1}{c|}{ Proposals } \\
\hline Indicators & Listening and learning & Professional vocation & Extended school time \\
& Evaluation & Activities in the area at risk & Peer tutoring \\
& Lack of trust & Valorisation of excellence & Curriculum revision \\
& Diploma & Failing exams & Valorisation of \\
& & Make-up lessons & students' interests \\
& & Laboratories & \\
\hline
\end{tabular}

\section{Findings related to the observation of the action phase}

As already indicated, after the analysis of the school actors expectations, representations and beliefs regarding school dropout and the promotion of students' success, different meetings and trainings were held with the participants.

With the teachers, five meetings were organised in order to develop the dimensions connected to self-efficacy, life skills, and the integration of these aspects within didactic activities. In particular, during the first meeting the goal of the educational intervention "A scuola di competenze" (Towards the school of competencies) was presented, as well as an introduction to life skills and peer education principles, as shown in Figure 1. 


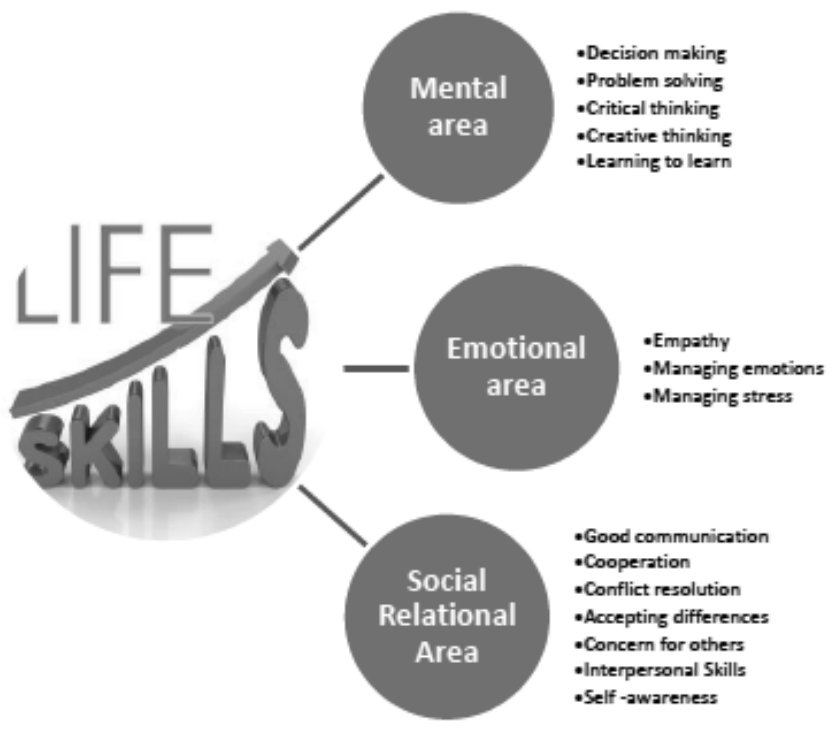

Fig. 1 (adapted from World Health Organization, 1994; Bussu et al., 2016; Bussu, Boyes-Watson \& Veloria, 2017).

The observation of the meetings highlighted the involvement of the participants and their engagement with the intervention. The teachers indicated the life skills necessary for themselves, for which they will need to be further "trained" and the competencies that the school needed to improve. All the contributions were discussed within the whole group of participants and the materials (individual checklists and trainer's supports) were collected. The following elements appeared as the main dimensions indicated by the teachers: problem solving; critical thinking; conflict resolution; empathy; selfefficacy; good communication; creativity; and the capacity to listen.

Concerning the students, four meetings were held in order to train four students to become peer educators. In particular, the topics connected to creativity, development of social skills, capacity to listen and self-awareness were presented and discussed with the participants. Students were then trained on the reparative practice of the peace circle (see Fig. 2), in which participants, working together in a circle, endorse an equalitarian role, outside of hierarchical models imposed by their status, age, etc. Students became aware of the skills necessary to ensure the role of a peer educator as a trainer. In addition, they were requested to collaborate in order to face the situations requiring problem solving, to recognise the role of the other and to endorse others' positions (as a student, as a teacher etc.). In the last two meetings, students practiced the perspective of the didactic activity alongside teachers, with the possibility of experimenting with the creative ways of teaching by playing (for different school subjects), and were asked to prepare lessons to be taught in the classroom. 

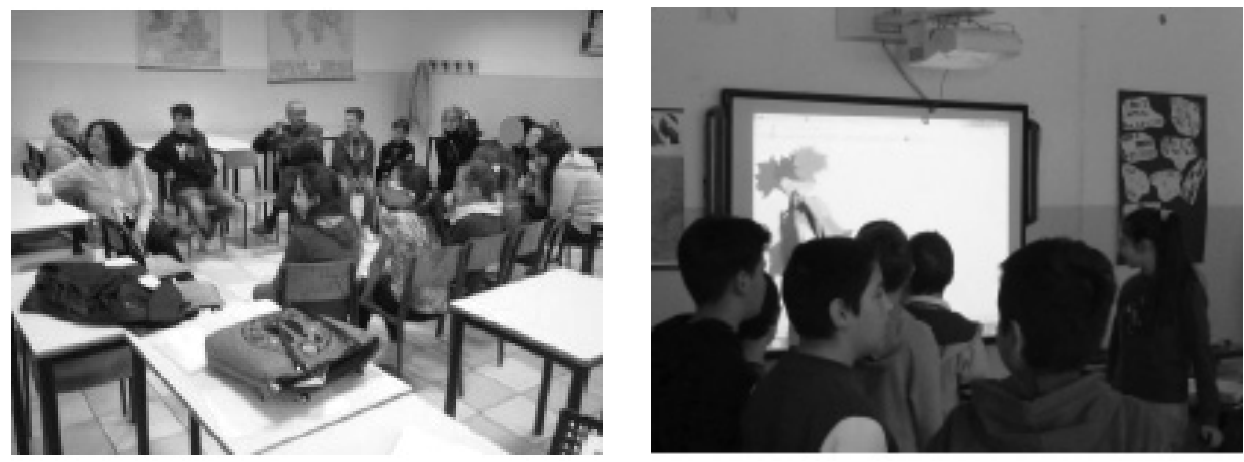

Fig. 2. Peace circle training and classroom activities conducted by peer educator.

Before teaching in classrooms, peer educators performed simulations of the lessons with the teachers of three classes. The feedback was aimed at offering suggestions, without any evaluative comments, in order to allow peer educators to test their skills. From April to May 2015, the lessons were performed in the classrooms. The entire responsibility for the lesson was taken by the peer educators. Teachers were invited to express their feelings about the performance of the students and declared their positive impressions about the seriousness in conducting the activities, the participation and interest of the students and the positive atmosphere in the classroom. In the same vein, peer educators indicated their positive experience, especially because of the possibility of meeting other people, of working in groups and of learning by playing and doing different activities. The experience was considered additionally useful because they learned how to listen and to be listened to by others, and they had the opportunity to perform new activities and forms of teaching/learning.

\section{Discussion and conclusion}

The project "A scuola di competenze" was developed in order to take into account the problems connected to the risk of dropout in the context that we observed and to promote new practices ensuring improved future school success. The critical aspects highlighted by school actors (teachers, students and parents) included a weak collaboration between the family and school, often because of parental "absence" and a lack of competence; from the teachers' side, a need to listen their students and to meet their personal and social needs.

The topic of the connection between school and the family is crucial and particularly interesting because of the potential benefits that school (and the family) can obtain by modelling a positive relationship between these 
two educational settings (Iannaccone \& Arcidiacono, 2014; Marsico et al., 2013). The intervention developed within the action-study represents an opportunity to question the representations of the school's role and to reflect on the new ways of promoting collaboration and participation, the ideas which are usually less developed.

Concerning the teachers' perspective, our study highlights how the observed school is strongly characterised by a subject tradition that leaves little room for transversal school competencies. For these reasons, students perceive the didactic offer as inappropriate with regard to the developmental changes of life, often imposed by the society. From within this perspective, peer education appears to be a possible modality for improving teachers' and students' life skills, in order to give students the opportunity to express their feelings and their potential and to establish new relationships with peers and adults. The idea of working on specific skills, such as the capacity to listen to others, was experienced through different activities, and, in particular, through the use of the peace circles. The promotion of good practices based on students' capacities and excellence should be more considered in the systems in which hierarchical and traditional ways of teaching/learning are often considered as the only ways for educating. The actions aimed at developing new opportunities and interventions are therefore crucial in order to demonstrate the potential benefits of each school, whilst still respecting a more general frame of the national system. The mandatory, permanent and structural educational system, enforced by national law, should be a process that accompanies the system in the above-mentioned direction, trying to highlight in primis the high professional profiles of teachers. Thereafter, the opportunities for lifelong learning can really contribute to improving the teachers' professional capacities within specific contexts (with peculiar needs and socio-historical characteristics) in order to promote more relational and psycho-pedagogic dimensions, "work by doing," and generally more collaborative practices.

The promotion of life skills through the peer education system could be an occasion for lifelong teachers' education, especially in respect to the recent indications of the educational goals indicated by the Italian Minister of Education, University and Research. However, these activities are still organised exclusively through experimental projects and local initiatives. Our intervention seems to promise a good direction towards the institutionalisation of these initiatives. In our research, we have observed the relevance of providing students with the opportunity to learn about risky behaviours at school, school dropout and its consequences. Through participation in training and other different activities (role-playing, simulations, brainstorming, small-group activities), the students involved in the program learned how to promote themselves as leaders and group animators in the classroom, as well as facilitators and mediators for interpersonal relationships. The fact that this 
kind of experience has been promoted with students of grade 6 is a challenge, but at the same time a good indicator of the necessity to improve different life skills, school success and collaborative actions before the secondary school (until today, the level of school more involved in experimental projects and measures). Through the development of social competencies and the involvement of teachers, students and parents, it is possible to improve the individual and collective efficacy necessary for school success: students and adults need to be supported in this endeavours in order to identify their educational priorities, recognise their representations and perspectives, and sustain practices based on the promotion of creativity, active listening, questioning and collaborative work (Berman et al., 1991).

The development and promotion of new models is therefore a key issue that concerns not only policy makers and teachers, but also students and their families, in order to create a community able to share goals, resources and practices that contribute to valuing the existing capacities and to provide new ways of teaching/learning. The development of different forms of social interactions in the classroom context (Giglio \& Arcidiacono, 2017) could contribute to this endeavour, as a relevant step toward the prevention of school dropout and the promotion of active participation and critical thinking in ensuring school success. We consider that the experience presented through the project, although partial and local, could be a useful starting point for a new qualitative perspective: the possibility of studying the perception of school dropout and the capacity for promoting school success requires the involvement of all the school actors, such as principals, teachers, students and parents. We are aware that further research is needed in this direction in order to identify the conditions more likely to create a network of schools and practices that promote good practices.

\section{Acknowledgements}

We are grateful to Prof. Patrizia Patrizi for the scientific supervision of the doctoral work that inspired the project (within a frame of collaboration between the Municipality of Sassari and the University of Sassari, Italy) and to Dr. Anna Bussu for the elaboration of the training's contents provided during the intervention.

\section{References}

Allensworth, E. (2005). Graduation and Dropout Trends in Chicago: A look at cohorts of students from 1991 to 2004. Chicago: Consortium on Chicago School Research.

Bandura, A. (1986). Social Foundations of Thought and Action: A Social Cognitive Theory. Englewood Cliffs: Prentice Hall.

Bandura, A. (1997). Self-Efficacy: The Exercise of Control. New York: Freeman and Company. 
Benvenuto, G., Rescalli, G., \& Visalberghi, A. (2000). Indagine sulla dispersione scolastica. Florence: La Nuova Italia.

Berman, L. M., Hultgren, F. H., Lee, D., Rivkin, M. S., \& Roderick, J. A. (1991). Toward curriculum for being. Albany: State University of New York Press.

Besozzi, E. (1997). Elementi di sociologia delleducazione. Rome: Nuova Italia Scientifica.

Boda, G. (2001). Life skill e peer education. Strategie per l'efficacia personale e collettiva. Florence: La Nuova Italia.

Boda, G. (2006). Leducazione tra pari. Linee guida e percorsi operativi. Milan: Angeli.

Boyes-Watson, C., \& Pranis, K. (2015). Building a restorative school community. St Paul: Living Justice Press.

Bullis, B. M. (1986). Dropout prevention. Berkeley: Policy Analysis for California Education.

Bussu, A., Quinde Reyes, M., Macias Ochoa, J., \& Mulas, E. (2016). Modelo de intervención Study Circle: promover la paz y el bienestar estudiantil con las prácticas restaurativas. In A. Rojas Garcia, G. Villalobos Monroy, K. Zarza Brunett \& J. P. Martinez Orosco (Eds.), Por una cultura de paz: Una mirada desde la Ciencias de la Conducta(pp. 216-230). México: Universidad Autónomadel Estado de México

Bussu, A., Boyes-Watson, C., \& Veloria, C. (2017). Study Circles: Promoting a restorative student community. Paper presented at AERA Annual meeting "Knowledge to Action: Achieving the Promise of Equal Education Opportunity". San Antonio, $27^{\text {th }}$ April $-1^{\text {st }}$ May.

Caprara, G. V. (2001). La valutazione dell'autoefficacia. Interventi e contesti culturali. Trento: Erickson.

Christenson, S. L., Sinclair, M. F., Lehr, C. A., \& Godber, Y. (2001). Promoting successful school completion: Critical conceptual and methodological guidelines. School Psychology Quarterly, 16, 468-484.

Christenson, S. L., \& Thurlow, M. L. (2004). School Dropouts: Prevention, Considerations, Interventions, and Challenges. Current Directions in Psychological Science, 13(1), 36-39.

Colucci, G. (2015). Dalla dispersione scolastica alla promozione del benessere nella scuola: primo monitoraggio di un intervento di formazione tra pari (Unpublished doctoral dissertation). Sassari: University of Sassari.

Colucci, G. (2016). From school dropouts to educational success. Policies and actions against early school leaving in the Italian school. In L. Lai, M. Mastinu, V. Saiu \& M. S. Schirru (Eds.), Ricerca in vetrina 2015. PhD in Sardinia: Higher Education, Scientific Research and Social Capital (pp. 469-476). Milan: Angeli.

Croce, M., \& Gnemmi, A. (Eds.) (2003). Peer education. Adolescenti protagonisti nella prevenzione. Milan: Angeli.

Franzese, C. (2009). La peer education. Synergy, 5(1), 15-28.

Giglio, M., \& Arcidiacono, F. (Eds.) (2017). Les interactions sociales en classe: réflexions et perspectives. Bern: Lang.

Hammond, C., Linton, D., Smink, J., \& Drew, S. (2007). Dropout risk factors and exemplary programs. Clemson: National Dropout Prevention Center, Communities in Schools. 
Iannaccone, A., \& Arcidiacono, F. (2014). Les relations école-famille: questions méthodologiques. In F. Arcidiacono (Ed.), Hétérogénéité linguistique et culturelle dans le contexte scolaire (pp. 147-156). Bienne: Editions HEP-BEJUNE.

Lehr, C. A., Hanson, A., Sinclair, M. F., \& Christenson, S. L. (2003). Moving beyond dropout prevention towards school completion: An integrative review of databased interventions. School Psychology Review, 32, 342-364.

Liverta Sempio, O., Confalonieri, E., \& Scaratti, G. (Eds.) (1999). Labbandono scolastico. Aspetti culturali, cognitivi, affettivi. Milan: Cortina.

Marsico, G., Komatsu, K., \& Iannaccone, A. (Eds.) (2013). Crossing Boundaries. Intercontestual Dynamics between Family and School. Charlotte: Information Age Publishing.

Morgagni, E. (1998). Adolescenti e dispersione scolastica. Possibilità di prevenzione e recupero. Rome: Carocci.

Olsen, L., \& Edwards, R. (1982). Push out, step out: A report on California's public school drop-outs. Oakland: Citizens Policy Center.

Roderick, M. (1994). Grade retention and school dropout: Investigating the association. American Education Research Journal, 31, 729-759.

Rumberger, R. W. (2004). Why students drop out of school. In G. Orfield (Ed.), Dropouts in America: Confronting the Graduation Rate Crisis (pp. 131-156). Cambridge: Harvard Education Press.

Scheier, M. F., Carver, C. S., \& Bridges, M. W. (1994). Distinguishing Optimism from Neuroticism (and Trait Anxiety, Self-Mastery, and Self-Esteem): A Reevaluation of the Life Orientation Test. Journal of Personality and Social Psychology, 67(6), 1063-1078.

Snyder, C. R., Harris, C., Anderson, J. R., Holleran, S. A., Irving, L. M., Sigmon, S. T., Yoshinobu, L., Gibb, J., Langelle, C., \& Harney, P. (1991). The will and the ways: Development and validation of an individual-differences measure of hope. Journal of Personality and Social Psychology, 60(4), 570-585.

World Health Organization (1994). Life skills education for children and adolescents in schools. Introduction and guidelines to facilitate the development and implementation of life skills programmes. Geneva: Global Programme.

World Health Organization (2003). Skills for Health. Skills-based Health Education Including. Life Skills: An Important Component of a Child-Friendly/Health-Promoting School. Geneva: Global Programme.

Zehr, H. (1990). Changing Lenses: A New Focus for Crime and Justice. Scottdale: Herald Press. 


\section{Ka prevenciji napuštanja škole putem obrazovanja vršnjaka: Eksplorativna analiza jednog akcionog istraživanja}

\section{Gabrijela Koluči}

Univerzitet za obrazovanje nastavnika, HEP-BEJUNE, Bil/Bjen, Švajcarska

\section{Frančesko Arćidijakono}

Univerzitet za obrazovanje nastavnika, HEP-BEJUNE, Bil/Bjen, Švajcarska

U radu se predstavlja eksplorativna analiza jednog akcionog istraživanja za prevenciju osipanja u jednoj italijanskoj srednjoj školi. Uzimajući u obzir predstave nastavnika, učenika i roditelja, razvijene su različite aktivnosti vršnjačkog obrazovanja kako bi se poboljšao školski uspeh tokom jedne školske godine u jednom gradu na Sardiniji. Studija je zasnovana na miks-metodskom nacrtu i uključivala je fokus grupe sa nastavnicima, učenicima i roditeljima, kao i posmatranje časova. Akciono istraživanje sastojalo se od različitih intervencija: najpre su prikupljene predstave učesnika o osipanju iz škole, zatim je predložen poseban program vršnjačkog obrazovanja kroz aktivnosti igranja uloga, simulacije, "brejnstorminga" i poboljšanja životnih veština (tokom programa obuke učesnika). Nakon toga, akciono istraživanje je analizirano kvalitativno, a nalazi su ukazali na moguće pravce revizije školskih praksi koje bi pomogle u sprečavanju osipanja.

Ključne reči: osipanje, akciono istraživanje, vršnjačko obrazovanje, kvalitativna analiza, poučavanje životnim veštinama 